\title{
UJI AKTIFITAS KOMBINASI EKSTRAK DAUN SIRIH MERAH ( Piper crocatum) DAN DAUN SIRSAK (Annona muricata L) DALAM PROSES PENYEMBUHAN LUKA
}

\author{
Anggara Joko Pratama, Rolan Rusli, Riski Sulistiarini \\ Laboratorium Penelitiandan Pengembangan FARMAKA TROPIS Fakultas Farmasi \\ Universitas Mulawarman, Samarinda, Kalimantan Timur \\ *Email: anggarajp92.ajp@gmail.com
}

\begin{abstract}
Abstrak
Penelitian ini bertujuan untuk mengetahui efektivitas dari kombinasi ekstrak daun sirih merah (Piper crocatum) dan ekstrak daun sirsak (Annona muricata L) untuk mempercepat penyembuhan luka. Metode yang digunakan yaitu pelukaan pada punggung tikus putih. Tikus putih dikelompokan menjadi 5 kelompok yaitu kelompok kontrol negatif yang diberikan $\mathrm{NaCl}$, kelompok kontrol positif yang diberikan Povidone Iodine, dan 3 kelompok uji yang diberikan kombinasi ekstrak tiga variasi dosis yang masing-masing diberikan secara topikal serta tiap tikus dikondisikan telah dilukai terlebih dahulu. Pengukuran kecepatan penyembuhan luka pada tikus berdasarkan ukuran luka yang dipantau setiap harinya hingga lukanya benar-benar sembuh. Hasil penelitian menujukkan bahwa kombinasi dari ekstrak daun sirih merah (Piper crocatum) dan ekstrak daun sirsak (Annona muricata L) memiliki potensi dalam penyembuhan luka yang lebih baik.
\end{abstract}

Kata Kunci: Piper crocatum, Annona muricata L, Luka, Tikus Putih.

\section{PENDAHULUAN}

Segala aktifitas dalam kehidupan sehari-hari dapat menimbulkan resiko timbulnya luka pada tubuh. Luka adalah terjadinya gangguan kontinuitas suatu jaringan sehingga terjadi pemisahan jaringan yang semula normal. Proses penyembuhan luka melalui beberapa proses yaitu fase inflamasi, pada fase ini terjadi hemostatis dan fagositosis kemudian dilanjutkan fase proliferasi dan fase maturasi (Karakata, 1996).

Berdasarkan uraian di atas maka penulis tertarik untuk meneliti kombinasi antara ekstrak daun sirih merah (Piper crocatum) dan daun sirsak (Annona muricata L) untuk mempercepat proses penyembuhan luka dibandingkan dengan obat-obat konvesional

\section{METODE PENELITIAN}

Penelitian ini merupakan penelitian eksperimental laboratoris dengan menggunakan metode secara in vivo. Penelitian ini merupakan penelitian pengembangan dari penelitan sebelumnya. Dimana pada penelitian sebelumnya ekstrak daun sirih merah memiliki aktifitas sebagai antibakteri dan ekstrak daun sirsak memiliki aktifitas antioksidan. Dimana dari penelitian ini didapatkan suatu kombinasi ekstrak antara ekstrak daun sirih merah dan ekstrak daun sirsak memiliki aktfitas sebagai obat luka.

\section{BAHAN}

Bahan yang digunakan adalah ekstrak daun sirsak, ekstrak daun sirih merah, kapas, $\mathrm{NaCl}$, Povidone Iodin 10\%, Metanol, perban dan plester 


\section{PERALATAN}

Alat yang digunakan adalah pisau bedah, alat pencukur, penggaris, cawan porselin, rotary evaporator, waterbath, neraca analitik, spidol

\section{HEWAN UJI}

Hewan uji yang digunakan adalah tikus putih galur wistar (Rattus norvegicus) dengan usia 2-3 bulan dengan bobot 200-300 gram dan tidak mengalami pengurangan bobot hingga $10 \%$ selama masa penelitian.

\section{PROSEDUR}

\section{Pengumpulan Bahan Tumbuhan}

Daun sirih merah dan daun sirsak diperoleh dari daerah Bengkuring kota Samarinda, Kalimantan Timur. Daun sirih merah dan daun sirsak dikumpulkan kemudian dibersihkan dari kotoran dan ditimbang beratnya sebanyak X gram, kemudian dikeringkan dengan cara diangin-anginkan didalam ruangan yang terlindung dari sinar matahari hingga diperoleh daun pacar kering. Selanjutnya daun pacar tersebut dipotong kecil-kecil dan siap dimaserasi. Bobot daun sirih merah kering dan daun sirsak kering yaitu Y gram

\section{Pembuatan Ekstrak}

Pembuatan ekstrak dilakukan dengan metode maserasi menggunakan pelarut metanol. Serbuk simplisia sebanyak Y gram yang siap dimaserasi dimasukkan kedalam toples transparan tertutup rapat dan dimaserasi dengan etanol sebanyak Y liter. Selanjutnya dilakukan pengadukan tiap berapa jam. Didiamkan selama 3 hari atau hingga warna pelarut menjadi pekat lalu ditampung maserat (hasil maserasi pertama). Diulangi perlakuan tersebut hingga diperoleh pelarut berwarna bening.

Maserat kemudian dipekatkan menggunakan rotary evaporator hingga diperoleh ekstrak kental. Sisa pelarut selanjutnya diuapkan di atas water bath hingga diperoleh ekstrak kering. Hasil pemekatan hasil maserasi sebesar Z gram.

\section{Uji Aktifitas Penyembuhan Luka}

\section{Penyiapan Bahan Uji, Kontrol dan Pembanding}

Kombinasi ekstrak metanol daun sirih merah dan ekstrak metanol daun sirsak dengan perbandingan $2: 1$, 1:1, dan $1: 2$ (bahan uji) povidone iodin $10 \%$ (pembanding) $\mathrm{NaCl}$ (kontrol)

\section{Uji Bebas Metanol}

Uji bebas metanol dilakukan terhadap ekstrak kering untuk meyainkan bahwa tidak ada lagi kandungan metanol dalam ekstrak daun sirih merah dan ekstrak daun sirsak. Karena dengan tidak adanya metanol akan mendukung peneitian bersifat valid tanpa adanya gangguan dikarenaka metanol juga dapat berperan sebagai antiseptik.

\section{Penyiapan Hewan Coba}

Hewan coba yang digunakan yaitu tikus putih (Rattus norvegicus) dewasa dengan berat antara 200-300 gram serta berusia 12-14 minggu dibagi dalam 5 (lima) kelompok yang masig-masing terdiri dari 3 ekor tikus.

Sebelum pengujian, hewan coba dipelihara pada kandang yang mempunyai ventilasi yang baik dan selalu dijaga kebersihannya. Hewan yang sehat ditandai dengan memperlihatkan gerakan yang lincah. 


\section{Pengujian Aktifitas Penyembuhan Luka}

Tikus dikelompokkan ke dalam 5 kelompok, yaitu kelompok pendahuluan kontrol negatif, kelompok kontrol negative $(\mathrm{NaCl})$, kelompok kontrol positif (Povidone iodin 10\%) dan kelompok bahan uji (tiga kombinasi ekstrak daun sirih merah dan dau sirsak).

Saat hari pengujian, masing-masing hewan ditimbang dan diberi tanda penomoran hewan coba, kemudian bulu tikus dicukur dengan alat cukur, dibuat luka pada punggung tikus dengan menggunakan pisau bedah. Setelah itu, masing-masing tikus dioleskan pada daerah luka kontrol dan bahan uji secara topikal sesuai dengan kelompoknya.

Pengamatan dilakukan dengan pengukuran panjang ukuran luka yang merupakan indikator kecepatan penyembuhan luka pada setiap harinya.

\section{HASIL DAN PEMBAHASAN}

Penelitian ini menggunakan 15 ekor tikus putih yang dinilai penyembuhan lukanya melalui pengukuran panjang luka tikus setelah pemberian perlakuan dan diamati hingga sembuh pada setiap harinya. Hasil rata-rata pengukuran panjang luka dapat dilihat pada table 1, grafik penyembuhan luka dapat dilihat pada grafik 1.

Tabel 1. Tabel Rata-rata Luasan Luka Sembuh

\begin{tabular}{|c|c|c|c|c|c|}
\hline \multirow{2}{*}{$\begin{array}{c}\text { Waktu Pengukuran } \\
\text { (Hari) }\end{array}$} & \multicolumn{5}{|c|}{ Rata-Rata Luasan Luka Sembuh } \\
\cline { 2 - 6 } & $\mathrm{K}+$ & $\mathrm{K}-$ & SM 2:1 S & SM 1:1 S & SM 1:2 S \\
\hline 1 & 3 & 3 & 3 & 3 & 3 \\
\hline 2 & 2,5 & 3 & 2,73 & 2,63 & 2,73 \\
\hline 3 & 2,27 & 2,57 & 2,3 & 2,35 & 2,5 \\
\hline 4 & 2,07 & 2,43 & 2,07 & 2,07 & 2,27 \\
\hline 5 & 1,67 & 2,17 & 1,57 & 1,6 & 1,73 \\
\hline 6 & 1,4 & 1,9 & 1,23 & 1,25 & 1,43 \\
\hline 7 & 1,1 & 1,5 & 0,8 & 0,9 & 1,1 \\
\hline 8 & 0,7 & 1,17 & 0,43 & 0,53 & 0,77 \\
\hline 9 & 0,5 & 0,93 & 0,067 & 0,27 & 0,5 \\
\hline 10 & 0,2 & 0,57 & 0 & 0 & 0,2 \\
\hline 11 & 0 & 0,27 & 0 & 0 & 0 \\
\hline 12 & 0 & 0 & 0 & 0 & 0 \\
\hline
\end{tabular}

Dari tabel diatas, terlihat bahwa kombinasi ekstrak daun sirih merah dan daun sirsak dengan berbagai variasi konsentrasi berpengaruh terhadapa penyembuhan luka. Hal ini didasarkan dari pada pengamatan setiap harinya mengalami perubahan dalam ukuran luka. 


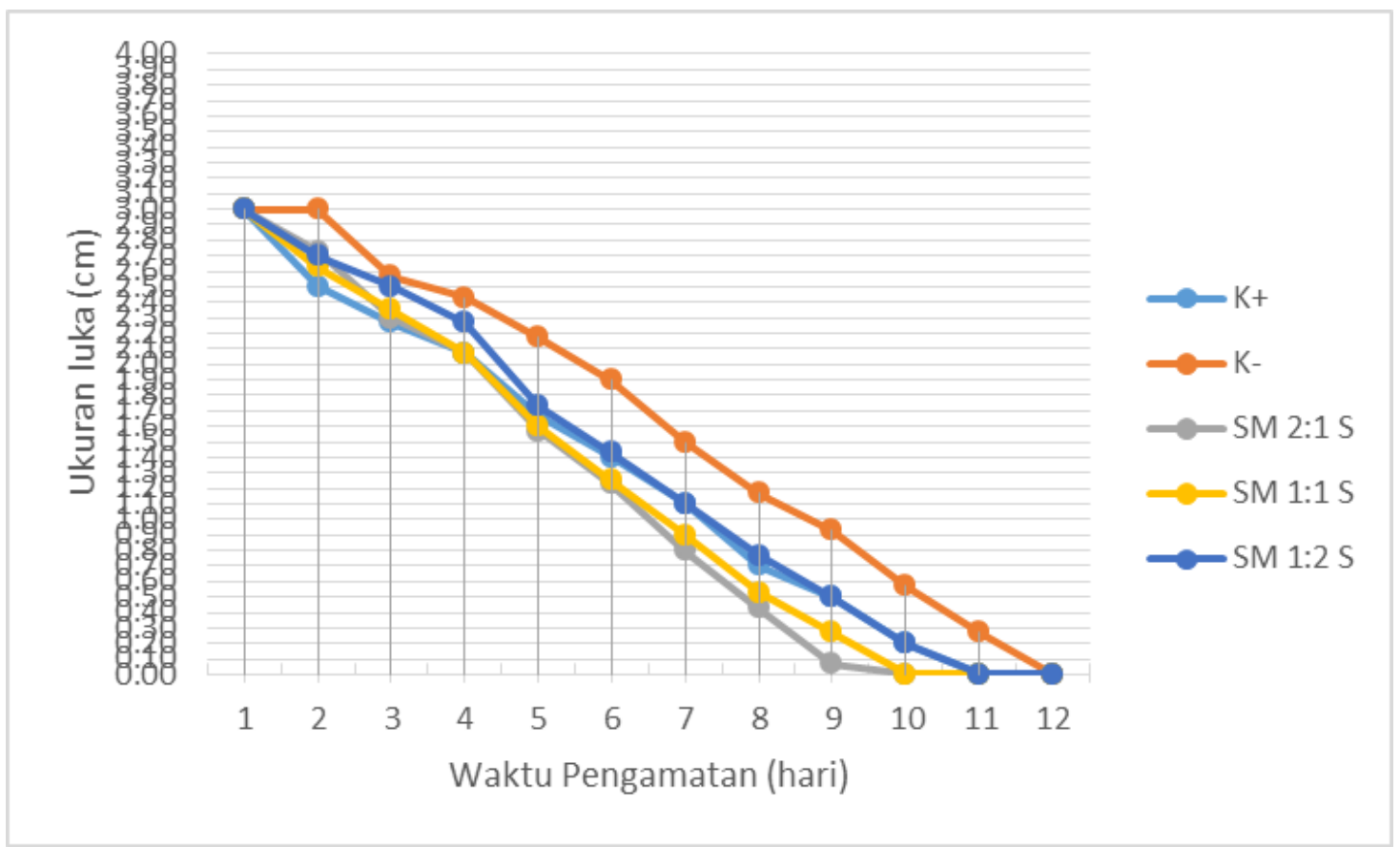

Grafik 1. Penyembuhan Luka Pada Hewan Uji

Pada grafik di atas dapat dilihat bahwa ekstrak dengan berbagai variasi kombinasi memiliki potensi sebagai penyembuh luka yang sama bahkan lebih baik dari sediaan povidone iodine $10 \%$ yang merupakan sediaan obat yang umum digunakan sebagai obat luka.

Pada kontrol positif dari 3 replikasi yang ada luka pada hewan uji yang diberi kontrol positif sembuh setelah 11 hari hal ini ditandai dengan luka yang sudah mengering dan tanda luka yang hilang tanpa meninnggalkan bekas luka. Kontrol positif ini menggunakan salah satu sedian yang sangat umum digunakan di pasaran yaitu povidone iodin $10 \%$ yang merupakan sediaan yang digunakan sebagai obat luka. Sediaan ini merupakan larutan antiseptik yang merupakan kompleks iodium dengan polyvinylpirrolidone yng tidak merangsang, mudah dicuci karena larut air dan stabil karena tidak menguap. Agen ini bekerja secepat Chlorhexidine dan memiliki spektrum yang lebih luas meliputi kerja sporasid dan pada penelitian ini, povidone iodin hanya bekerja membantu mempercepat proses fagositosis. Dari hal ini jika ditarik sebuah perbandingan jika dibandingkan dengan kombinasi ekstrak dari beberapa varian yang bisa bekerja pada fase inflamasi dan proliferasi sehingga hewan coba yang menggunakan kombinasi ekstrak dengan perbandingan ekstrak sirih merah dan ekstrak daun sirsak 2:1 dan 1:1 lukanya lebih cepat sembuh. Akan tetapi ada 1 hal yang menarik kontrol positif jika dibandingkan dengan kombinasi ekstrak daun sirih merah dan daun sirsak dengan perbandingan 1:2 hasilnya sama luka sembuh pada 11 hari. Hal ini, Jika dibandingakn dengan kontrol negatif, pada kontrol positif lebih dahulu dan permaslahan ini sesuai dengan teori yang ada.

Dari penelitian ini terlihat bahwa kombinasi ekstrak daun sirih merah dan daun sirsak yang memiliki perbandingan ekstrak daun sirih merah yang lebih besar atau sama dengan ekstrak daun sirsak memiliki efek penyembuhan luka yang lebih cepat. Hal ini dikarenakan kandungan senyawa pada daun sirih merah berupa flavonoid, alkaloid, senyawa polifenolat, tannin dan minyak atsiri yang memiliki aktifitas dalam penyembuhan lukan yang lebih baik. Flavanoid berperan dalam fase inflamasi dengan menghambat enzim proinflamasi seperti, COX - 2, lipoksigenase, dan NO serta menghambat sitokin yang 
berperan dalam proses inflamasi seperti TNF- $\alpha$, IL-1 $\alpha$, dan IL-2. Alkaloid berperan dalam meningkatkan proliferasi limfosit dan aktivitas IL-2. Proliferasi limfosit mempengaruhi sel TCD4+ yang kemudian akan mengaktifkan sel Th1 yang mempengaruhi IFN- $\gamma$. IFN- $\gamma$ mengaktifkan makrofag sehingga fagositosis mikroba berlangsung lebih cepat dan efisien. Tanin berperan dalam penghentian pendarahan atau lebih dikenal dengan vasokontriksi dengan mekanisme kerjanya mempercepat keluarnya proteindari sel dan mengendapkan protein tersebut pada permukaan sel, juga mengurangi sekresi dan permeabilitas kapiler, kontraksi ruang antar sel, pengerasan endotolium kapiler, dan kemudian membentuk lapisan pelindung kulit sehingga lapisan superfisial sel mengencang dan menyusut. Keadaan ini akan menghasilakn vasokontriksi local dari kapiler. Senyawa pada sirih merah selain berperan dalam aktifitas anti inflamasi, juga berperan dalam pemicu tejadinya kontraksi pada luka dan peningkatan tonus pembuluh darah serta menghancurkan senyawa radikal bebas dan berperan sebagai antiseptic sehingga menyebabkan percepatan periode epitelisasi daerah luka.

Kombinasi ekstrak daun sirih merah dan daun sirsak dengan perbandingan 2:1 dan 1:1 luka sembuh dalam 10 hari lebih cepat daripada kontrol positif yang berarti memiliki kemampuan yang lebih dalam penyembuhan luka jika dibandingkan dengan salah satu sediaan yang secara luas digunakan sebagai obat luka dan berpotensi sebagai kandidat obat luka baru yang lebih efektif untuk kedepannya. Jika dilihat kedua kombinasi ini memiliki waktu yang sama dalam hal penyembuhan tetapi setelah ditelusuri lebih detail pada tabel hasil pengamatan maka dapat dilihat pada tiap harinya pengurangan luas luka dari kombinasi ekstrak daun sirih merah dan daun sirsak 2:1 lebih besar jika dibndingkan dengan 1:1.

\section{KESIMPULAN}

Pada penelitian ini proses penyembuhan luka pada hewan coba selama 10 hari pada kombinasi daun sirih merah 2:1 daun sirsak dan kombinasi daun sirih merah 1:1 daun sirsak. Hal ini menandakan bahwa kombinasi ekstrak daun sirih merah dan ekstrak daun sirsak berpotensi dalam hal mempercepat penyembuhan luka.

\section{DAFTAR PUSTAKA}

Depkes RI. 1979. Farmakope Indonesia III. Depkes RI : Jakarta.

Depkes RI. 1980. Materia Medika Indonesia Jilid IV. Depkes RI: Jakarta.

Fajariah, Ika Nur. 2009. Uji Aktivitas Antibakteri Fraksi Etil Asetat Ekstrak Etanol Kayu Secang (Caesalpinia sappan L.) terhadap Staphylococcus aureus dan Shigella dysenteriae serta Bioautografinya. Universitas Muhammadiyah: Surakarta.

Harbone, J.B. 1987. Metode Fitokimia. ITB Press: Bandung.

Hermawan, Galih Prihasetya dan Hendrawan Laksono. 2013. Ekstraksi Daun Sirsak (Annona muricata L.) Menggunakan Pelarut Etanol. Jurnal Teknologi Kimia dan Industri Volume 2 Nomor 2.

Irawan, Bambang. 2010. Peningktan Mutu Minyak Nilam dengan Ekstraksi dan Destilasi pada Berbagai Komposisi Pelarut. Universitas Diponegoro: Semarang.

Guyton, A.C. dan John E.H. 1997. Buku Ajar Fisiologi Kedokteran. EGC : Jakarta.

Karakata, S. dan Bob B. 1996. Bedah Minor.Hipokrates: Jakarta

Latief, Abdul. 2009. Obat Tradisional. EGC: Jakarta.

Manjang, Y. 2006. Penelitian Kimia Bahan Alam untuk Pelestarian dan Pengembangan Tumbuhan melalui Tanaman Agrowisata. Dirjen Dikti Depdiknas : Padang.

Murniasih, T. 2003. Metabolit Sekunder dari Spons Bahan Obat-Obatan. Oseana Volume XXVIII Nomor 3. www.oseanografi.lipi.go.id. (diakses tanggal 23 Maret 2013) 
Raina, M. H. 2011. Ensiklopedi Tanaman Obat Untuk Kesehatan. Absolut ; Yogyakarta.

Sa'ad, Muhammad. 2009. Uji Aktivitas Penangkap Radikal Isolat A dan B Fraksi IV Ekstrak Etanol Daun Dewandaru (Eugenia uniflora L.) dengan Metode DPPH. Universitas Muhammadiyah: Surakarta.

Sarker, S. D. 2009. Kimia Untuk Mahasiswa Farmasi. Pustaka Pelajar; Yogyakarta.

Sudewo, Bambang. 2010. Basmi Penyakit dengan Sirih Merah. Agromedia Pustaka : Jakarta

Voight. R. 1994. Buku Pelajaran Teknologi Farmasi. Gajah Mada University Press : Yogyakarta.

Wallace, M. 1984. The Mouse in Residence and Transit. UFAW : Hertfordshire.

Widyaningrum, H. 2011. Kitab Tanaman Obat Nusantara. Medpress: Yogyakarta. 